\title{
Cinsiyetlendirilmiş Bir Egzersizin Sınırlarında: Adana'daki Erkeklerin Pilates Deneyimleri
}

\author{
DOI: $10.26466 /$ opus.587527
}

\author{
Mehmet Bozok* $^{*}$ Z. Merve Munar** - İrem Kavasoğlu*** \\ * Dr. Öğr. Üyesi, Maltepe Üniversitesi, İnsan ve Toplum Bilimleri Fakültesi, İstanbul / Türkiye \\ E-Posta: mehmetbozok@maltepe.edu.tr ORCID: 0000-0002-9841-6324 \\ ** Lisans Öğrencisi, Çukurova Üniversitesi, Beden Eğitimi ve Spor Yüksek Okulu, Adana / Türkiye \\ E-Posta: zahidemervemunar@gmail.com ORCID: 0000-0002-0461-2675 \\ *** Öğr. Gör. Dr., Çukurova Üniversitesi, Beden Eğitimi ve Spor Yüksek Okulu, Adana / Türkiye \\ E-Posta: kavasogluirem@gmail.com ORCID: $\underline{0000-0003-3969-1163}$
}

\section{Öz}

Bu çalışma, cinsiyetlendirilmiş bir egzersiz olarak pilatesi Adana'da bu egzersizi yapan erkekler üzerinden ele alıyor. Pilates, erkek kimliği ve ataerkil erkeklikler için toplumsal olarak uygun görülmeyen bir egzersizdir. Bu bağlamda amacımız, ataerkilliğiyle bilinen bir kent olan Adana'da tenis kulübüne giden eğitimli ve orta üst sınıfa mensup erkeklerin cinsiyetlendirilmiş ve kadınlara özgü bir egzersiz olarak inşa edilen pilatesteki deneyimlerini ve pilatese yükledikleri anlamları irdelemektir. Bu araştırmada niteliksel yöntem kullanılarak, pilates yapan altı erkekle derinlemesine görüşmeler yapılarak veri toplanmıştır. Toplanan veriler, içerik analizi yöntemiyle analiz edilmiştir. Araştırmanın bulguları katılımcların pilatesi bağımsız bir egzersiz olarak değil de bir performans sporu olarak gördükleri tenise destek olacak bir egzersiz olarak tanımladıklarını ortaya koymaktadır. Bu araştırma, katılımcı olan erkeklerin pilatese başlama ve pilatesi sürdürme motivasyonunun sağlıklı yaşam söylemi ve erkeklik performansını koruma çabasıyla iç içe geçtiğini ve katılımcıların pilates deneyimlerinde kendi erkeklik söylemleri ve pratiklerinin ön plana çıktığını göstermektedir. Sonuç olarak, Adana'da pilates yapan katılımoı erkeklerin ataerkil erkeklik kodlarının bu egzersize yükledikleri anlamlara da yansıdığg görülmektedir.

Anahtar Kelimeler: Spor Sosyolojisi; Toplumsal Cinsiyet; Pilates; Erkeklikler; Adana 


\title{
On The Borders of A Gendered Exercise: Pilates Experiences of Men in Adana
}

\begin{abstract}
This study examines Pilates as a gendered exercise focusing on men doing this exercise in Adana. Pilates is considered as a socially inappropriate exercise for male identity and patriarchal masculinities. In this context, our aim is to examine the experiences of educated and middle-class men who attend to the tennis club in Adana, a city known for patriarchal qualities; and the meanings they attribute to pilates, which is built as a gendered exercise, coded peculiar to women. In this study, in-depth interviews were conducted with six men pilates using qualitative research methods. The collected data were analyzed using content analysis method. The findings of the study reveal that the participants identified pilates as an exercise that would support the tennis, which they considered as a performance sport, not as an independent exercise. This study shows that the motivation of participating men to start and maintain pilates is intertwined with the effort to maintain healthy lifestyle discourse and masculine performance and that the participants' own discourse and practices of masculinity are prominent in their pilates experience. As a result, it is seen that the patriarchal masculinity codes of the participating males doing pilates in Adana also spread to the meanings they impose on this exercise.
\end{abstract}

Keywords: Sociology of Sports, Gender, Pilates, Masculinities, Adana, 


\section{Giriş}

Toplumsal cinsiyet ilişkileri, bir taraftan sporlara yüklenen toplumsal ve kültürel anlamları, diğer taraftan da bunları sarmalayan ilişki ağlarını içerir. Spor, egzersiz ve fiziksel aktivite, mevcut toplumsal cinsiyet ilişkilerinin yansıdığı, üretildiği ve hatta yeniden üretildiği alanlardır. Gündelik hayatta karşımıza çıkan ataerkil ve cinsiyetçi toplumsal cinsiyet ilişkiler spor ve egzersizlere aktarılır. Buna karşılık olarak spor ve egzersiz de hem toplumsal cinsiyet ilişkilerinin deneyimlenmesi için alanlar sunar, hem de bu alanlarda yeni cinsiyet kodlarının üretimine katkı sağlar. Bu durum, belirli cinsiyetlerden aktörlerle ilişkilendirilen -genelde erkeklerle ilişkilendirilen futbol, halter, dövüş sporları ya da kadınlarla ilişkilendirilen cimnastik, buz pateni, yoga ya da pilates gibi- "cinsiyetlendirilmiş" spor ve egzersizlerde daha da belirgindir. Cinsiyetlendirilmiş sporlar ve egzersizler, sözkonusu aktiviteye yüklenen toplumsal anlamlardan ötürü -aktörler için- başından itibaren dışında kalınması zor, hakim ataerkil toplumsal cinsiyet ilişkilerinin alanıdırlar. Böylece aynı cinsiyetten aktörlerin yer aldığı ve mevcut cinsiyet kodlarının sürdürülmesine katkıda bulunan homososyal alanlar yaratırlar. Pilates de bu alanlardan biridir.

Cinsiyetlendirilmiş ve günümüzde neredeyse tamamen kadınlarla ilişkilendirilen bir egzersiz olarak pilates, erkekler ve erkeklik için uygun görülmez (Markula, 2006; Messner, 2000). Rehabilitasyon kökenli bir egzersiz olarak pilates, güçlenme, rekabet veya sertlikten ziyade ve esnekliğe yöneliktir. Güçlü ve kaslı erkek bedeninin inşası, rekabet, sertlik, saldırganlık ve acıya karşı dayanıklı olma gibi erkeklik idealleri için gerekli görülen pek çok özelliği taşımaz. Bu durum onu özellikle ataerkil erkeklikler için hassas, netameli ve kriz yaratma potansiyeli olan bir alan hâline getirir. Ataerkil erkeklikler, hegemonik erkeklik ideallerinin taşıyıcıları, yararlananları ve yeniden üretenleri olarak, mevcut cinsiyet kodlarını yansıtan en önemli aktörlerden biridir.

$\mathrm{Bu}$ araştırmada, cinsiyetlendirilmiş spor ve egzersizlerin, sözkonusu cinsiyetlendirilmiş alanın ilişkilendiği cinsiyetin diğer tarafında kalan aktörlerce hangi söylem ve pratikler yoluyla nasıl kurulduğu, deneyimlendiği ve paylaşıldığını anlamak için, pilates yapan erkeklere yönelinmiş̧tir. Bu nedenle de cinsiyetlendirilmiş bir egzersiz olarak pilatesi ataerkil kod- 
ların ve ataerkil erkekliklerin yoğun olduğu, ataerkilliğiyle -ve ataerkil erkeklikleriyle- bilinen bir şehir olan Adana'da pilates yapan erkeklere odaklanılarak incelenmiştir ${ }^{1}$.

Bu yazı, spor ve erkeklikler arasındaki toplumsal ilişkileri merkeze alarak, cinsiyetlendirilmiş bir egzersiz olan pilates ve erkeklikler arasındaki ilişkilerin nasıl kurulduğunu, ataerkilliğiyle bilinen bir şehirde kadınlarla ilişkilenen bir egzersiz olan pilates yapan erkeklere odaklanarak tartışmaktadır. Araştırmayı tasarlarken iki temel soruya yanıt aranmıştır. İlkin “ataerkilliğiyle maruf bir kent olan Adana'da -tenis kulübüne giden eğitimli ve orta üst sınıfa mensup- erkeklerin cinsiyetlendirilmiş ve/ya kadınlara özgü bir egzersiz olarak inşa edilen pilates deneyimleri nelerdir?" İkinci olarak da "erkeklerin pilatese yükledikleri anlamlar nelerdir?" Dolayısıyla hem makalenin araştırma sorusunu, hem de yapılan tartışmayı cinsiyetlendirilmiş egzersiz olarak pilates ve (ataerkil) erkeklikler ile deneyim ve anlamlar üzerine kurulmuştur. Bunları ortaya koyabilmek adına, izleyen bölümlerde tartışılan 2018 Mart ayında Adana'da pilates yapan erkeklerle derinlemesine görüşmeler yapılarak niteliksel bir araştırma gerçekleştirilmiştir. Aşağıda ilk olarak bu araştırmanın arkasındaki kuramsal tartışma, araştırmanın metodolojisi ve arka planı ele alınacak. Ardından da araştırmanın bulguları tartışılacaktır.

\section{Kuramsal Tartışma: Cinsiyetlendirilmiş Sporlar, Erkeklikler ve Pilates}

Sporun toplumsal cinsiyet halleri ile ilgili 1970'lerden bu yana gelişen literatür, bize bu alanın büyük ölçüde erkek egemen ilişkilerce şekillendirildiğini ortaya koymaktadır (Öztürk, 2016, s.38). Spor, mevcut toplumsal cinsiyet ilişkilerini yeniden üreten ve inşa eden fakat kendi kuralları ve

\footnotetext{
1 Bu çalışmanın iki temel özgünlüğü bulunmaktadır. Araştırma bir yandan uluslararası literatürde ilk pilates sosyolojisi çalışmalarından biridir. Diğer yandan da pilatesi erkeklikler ile ilişkisi bağlamında ele alan ilk çalışmadır. Bu nedenle Adana'da pilates yapan erkeklerin ataerkil erkeklikler ile ilişkisine dair bu makalenin ortaya koyduğu tartışmalar, spor sosyolojisi ve eleştirel erkeklik çalışmalarında üzerine ilk defa söz söylenmiş bir alandan damıtılmıştır. Böylece literatür için de yeni araştırma sorularına kapı aralayan bir araştırma olma misyonu da taşımaktadır. Ancak bu araştırma için altını çizmemiz gereken bir nokta daha bulunmaktadır. Bu araştırma Adana'daki erkeklikler hakkında da önemli bilgiler vermesine karşın burada asıl amacımız Adana erkekliğini incelemek için pilatese bakmak değildir. Ancak pilates tartışırken görüştüğ̈̈müz erkeklerin kendilerinin ve sosyal çevrelerinin erkeklik söylemleri ve pratikleri, Adana'daki erkeklikler üzerine çalışmalar için kayda değer ipuçları da sunmaktadır.
} 
özgül dinamikleri olan bir alandır. Spor ve toplumsal cinsiyete dair bu literatür, rekabet, sertlik, mücadele içeren sporları erkeklere yakıştırıldığını ve bu sporların erkeklikle ilişkisini fanatik bir biçimde kurduğunu göstermektedir (Bora, 2010; Csizma, Wittig ve Schurr, 1988; Koivula, 1995; 1999; 2001; Matteo, 1986). Bu nedenle futbol başta olmak üzere boks, güreş, rugby, dövüş sporları, vücut geliştirme gibi sporlar erkekliğin dolaşıma girdiği ve yeniden inşa edildiği sporlardır (Adams, 2011; Bulgu, 2012; Gillett ve White, 1992; Hacısoftaoğlu, 2012; Kavasoğlu ve Yıkılmaz, 2018; Koca ve Bulgu, 2005; Schmalz ve Kerstetter, 2006; Tokdoğan, 2015). Bunun aksine çok yoğun temas içermeyen, daha hafif ve estetik sporlar ise kadınlara uygun olarak kodlanır. Bu bağlamda modern sporların ortaya çıktığı 19. yy sonlarından beri kadınlara ağır, zor veya hızlı hareketler içeren sporlar yerine "kendi keyifleri için kibar sporlar, stilin büyük önem taş1dığı estetik sporlar ya da kadın cimnastiği" yapılmasının önerilmiştir (Bonde, 2003, s. 104). Buna göre de cimnastik, buz pateni, aerobik, dans, yoga ve pilates gibi egzersizler ve sporlar kadınlara yakıştırılır ve kadıns1lıkla ilişkilendirilir (Hardin ve Greer, 2009; Koca ve Demirhan, 2005; Markula, 2008; Riemer ve Visio, 2003).

Kadınlara ve erkeklere "uygunluk" anlatısı, toplumsal cinsiyet rejiminin bir sonucu olarak bu spor dallarındaki cinsiyet eşitsizliğini en keskin şekilde görmemize olanak sağlar. Dans eden erkekler (Kavasoğlu, Rençbereli ve Yenel, 2017) ya da boks yapan kadınlar (Emir, Karaçam ve Koca, 2015) örneklerinde de görüldüğü üzere, alandaki hakim toplumsal kabullerin dışındaki cinsiyet kodlarıyla hareket eden sporcular, toplumsal bariyerlere çarpmakta (Kavasoğlu ve Yaşar, 2016) ve ayrımcllığa maruz kalmaktadır. Bu noktada araştırmanın konusuyla da ilişkisi olması bakımından dikkat çekici olan diğer bir nokta da erkeklerin kendi cinsiyetlerine uygun sporlara yönelmede kadınlardan daha tutucu olduğudur. Matteo'nun işaret ettiği üzere,erkekler cinsiyetlerine uygun olmayan sporları reddetmede, kadınlardan daha fazla toplumsal cinsiyet kalıp yargilarını öne sürmektedirler (1988). Nitekim bu bulgu ile ilgili araştırmalar, kadınların erkeksi görülen sporlara katılımının erkeklerden daha kabul edilebilir görüldüğünü ve erkeklerin kadınsı olarak değerlendirilen sporlara katılımının onların erkeklikleriyle ilgili potansiyel sorgulamalara yol açtığını ortaya koymaktadır (Riemer ve Visio, 2003; Schmalz ve Kerstetter, 2006). 
Bu durum kuşkusuz ataerkilliğin kendi erkekliğini kurarken "hegemonik" sınırlar çizmesi ve bu sınırların dışında kalma tehlikesinin ağır basması ile ilişkilidir. Bir diğer deyişle bu durum, "erkeklik meselesinin" yüce, aşkın ve ayrıcalıklı görülmesiyle bağlantılıdır. McKay, Messner ve Sabo'nun (2000) işaret ettikleri üzere, eleştirel erkeklik çalışmaları spor ve erkeklikler arasındaki ilişkileri ele alırken feminist ve cinsiyetçilik karşıtı bir duruştan hareket etmelidir. Bu kuramsal konumlanışın en önemli vurgularından biri de hakim erkeklik inşalarının eleştirisine ilişkindir.

Farklı "erkekliklerin" nasıl inşa edildiğini ele alan erkekler ve erkeklikler üzerine eleştirel incelemeler alanının önde gelen isimlerinden Connell'ın "hegemonik erkeklik" fikri, belirli bazı erkeklik inşalarının kadınlar ve öteki erkekler üzerinde egemenlik kurmada -ve onların rızasını almada- diğer erkekliklerden daha elverişli stratejiler geliştirdiğini imler (Connell, 1998; 2005; Connell ve Messerschmidt, 2005). Hegemonik erkeklik inşaları, erkeklerin ulaşmak için çaba gösterdikleri erkeklik idealleridir. Modern sporlar 19. yy sonlarında ortaya çıarken, erkeklerin fiziksel ve psikolojik olarak güçlenmeleri ve kendilerini disipline etmeleri için bir araç olarak kullanılmıştır (Bora, 2013; Wellard, 2009, ss. 10-12). Atletik beceriler ve spordaki başarılar, "erkek üstünlügünü" kanıtlamanın aracı olarak görülmüştür. Fakat günümüzde -profesyonel sporcular bir kenara b1rakılacak olursa- spor "işin dışında" ve "boş" zamanda erkeklerin kendi kimliklerini kurabilecekleri beden idealleri, söylemler, pratikler ve ilişkilerle çevrili bir alan haline gelmiştir.Bu bağlamda Connell ve Messerschmidt'in işaret ettiği üzere, günümüzün hegemonik erkeklik imgesinin inşasında bakımlı ve sağlıklı görünmek ve düzenli olarak spor ve fiziksel aktiviteyle uğraşmak önemli bir yer tutmaktadır (2005, s.833-835).

Hegemonik erkeklik idealleri, erkeklerin kadınlar ve diğer erkekler üzerinde iktidar sahibi olmak için kendilerini her daim güçlü, fiziksel olarak formda, rekabetçi, cinsel olarak her zaman talepkâr ve muktedir, duygularını her zaman belli etmeyen ve kimi zaman bakımlı kimi zaman da çok da bakımlı olmayan-ancak aynı zamanda da kadınlarla ve eşcinsellikle ilişkilenmekten kaçınan kimseler olarak kurmalarını öngörür. Spor, hegemonik erkeklik ideallerinin kurulduğu, yeniden üretildiği, kimi zaman da iktidar olmanın yeni yollarının bulunduğu -birbiriyle çelişkili olabilen- pratikler, söylemler ve simgeleri içermektedir (Messner, 2005). Böylece erkekler için ideal bedene sahip olma, rekabetçilik, hız, rekor kırma, 
iktidar sahibi olma, fiziksel olarak daima güçlü olma, dayanıklı olma, iktidar sahibi olma, esneklik, sağlıklı, fit ve zinde olma gibi -kimi birbiriyle çelişkili veya bir arada gerçekleştirilmesi mümkün olmayan- özelliklerin geçekleştirilmesinin amaçlandığı bir alandır (cf. Messner, 2005; 2007). Bu ilk bakışta çelişkilerle dolu özellikler bütünü erkek(lik)lere farklı bağlamlarda iktidarlarını kurabilmek için son derece esnek bir hareket alanı sunar.

Erkekliklerin sporda bedenlenmesi (embodiment) Connell'ın işaret ettiği üzere "belirli organların değil, tüm bedenin harekete geçmesini" imler (2005, s.54). Mevcut toplumsal cinsiyet ilişkileri, spordaki bedensel performanslarda somutlaşır ve bedene ilişkin söylemlerde simgeselleştirilir (s.54). Erkekler arasındaki toplumsal hiyerarşiler, çekişmeler, kadınların ve öteki erkeklerin dışlanması sporda karşılığını bulur. Spor, erkekler arasındaki ilişkilerde erkeklerin kadınları, LGBTI'leri ve bunlarla ilişkilendirilen değerler, mekânlar, pratikler ve ilişkileri ötekileştirmesinin önemli zeminlerinden biridir. Messner'ın da işaret ettiği üzere, erkekler için spor, genellikle kendilerini kadınlardan, LGBTI'lerden ve öteki erkeklerden ayırmak ve onlar üzerinde iktidar kurmak için kullandıkları kurumsallaşmış bir alandır (2005, s.314). Ancak spor aynı zamanda "çekişmeli bir mıntıkadır" (Messner, 2005, s.314; 2007, s.4). Salt cinsiyet ataerkil ve cinsiyetçi ilişkileri yeniden üretmez, kimi zaman da cinsiyet hiyerarşilerinin aşınd1rıldığı, bizzat cinsiyetçiliğin sorgulandığı veya cinsiyet eşitliğinin olanaklarının tartışıldığı itirazlar ve direnişlerin yaşandığı zeminler olarak karşımıza çıarlar.

Spor ve egzersiz, günümüzde farklı kimseler için farklı anlamlara gelse de herkesin bir şekilde gerçekleştirebileceği bir etkinlikler bütünü olarak kurgulanmaktadır. Bu durum son dönemde yeni fitness salonları, besin destekleri, yaşlanmayı önlediği iddia edilen besinler, ya da popüler spor dalları ve fiziksel egzersizler gibi yeni ürünlerin ortaya çımasına yol açmiştır. Spor ve egzersiz yapmak, Parker'ın da işaret ettiği üzere, günümüz tüketim toplumlarında erkek bedenine ilişkin hegemonik ideallerine ulaşmaya çalışmada erkeklerin "iyi gözükmek" ve "kendilerini iyi hissetmek" gibi amaçları gerçekleştirirken kullandıkları araçlardan biridir (1997, s.130-131). Erkekler için fiziksel olarak "fit olmak", spor ve egzersiz yap1yor olmak, sağlıklı beslenmek, gündelik yaşamın ve zaman içinde yaşlanmanın getirdiği, yarattığı yıkımlar karşısında bedenini disipline etmeyi ve 
korumayı ve hatta özenli, bakımlı ve çekici olmayı temsil etmektedir. Bu bağlamda hegemonik üst ve üst orta sınıfın mevcut hegemonik erkeklik idealleri bağlamındaki, yoga ve pilates gibi çağdaş ve moda haline gelen aktiviteler erkeklerin sağlıklı, yakışıklı, zinde beden imgesine ulaşmaya çalışmak için yararlandığ 1 pratikler arasındadır (cf. Sancar, 2009, s.74-75). Ancak, Messner'ın (2000) vurguladığı üzere, ağırlık kaldırmak kadınlar için nasıl asla düşünülemeyecek bir fiziksel egzersiz olarak görülüyorsa, benzer bir biçimde yoga ve pilates de erkekler için böyle görülmektedir.

Cinsiyetlendirilmiş bir pratik olarak günümüzde özellikle kadınlar arasında oldukça popüler bir egzersiz olan pilates, temelde fizik tedavi kökenli, bedensel esnekliği arttırmayı hedefleyen bir egzersizdir². Bundan dolayı mevcut pilates literatürünün büyük bir kısmı, pilatesin sağlıkla ilişkisini ele almaktadır. Bu çalışmalarda pilates, temel motor becerilerin geliştirilmesinde, vücut kompozisyonunun iyileştirilmesinde ya da farklı beden bölümlerinin rehabilitasyonun bir parçası olarak ele alınmakta, pilates egzersizlerinin sonuçlarına odaklanılmaktadır (Anderson, 2005; Jago et al., 2006; Johnson et al., 2007; Segal, Hein ve Basford, 2004). Bunun yanı sıra pilatesin psikolojik faydalarını ele alan bir literatür de bulunmaktadır (Aibar-Almazán et al., 2019; Cruz-Ferreira et al., 2011; Mokhtari, Nezakatalhossaini ve Esfarjani, 2013). Türkiye'deki pilates literatürü de fizyoloji, fizyoterapi ve rehabilitasyon ve psikoloji odaklı çalışmalara dayanmaktadır (Kılıç, Uğurlu ve Dikdağ, 2018; Özkul, 2017; Saltan, 2018; Tingaz, 2018). Pilatesin sosyolojisi üzerine ise -satır aralarında yapılan bazı değiniler hariç-neredeyse hiç çalışma bulunmamaktadır (Markula, 2003; Messner, 2005; Sancar 2009). Bunun yanı sira hem ulusal hem de uluslararası literatürde pilates çalışmalarının öznesini çoğunlukla kadınlar oluşturmaktadır. Bu bilimsel çalışmaların dışında pilates üzerine popüler kültür kitapları da bulunmaktadır. Bu kitaplarda da çoğunlukla resimli görseller kullanılarak hareketlerin nasıl yapılacağı tarif edilmektedir. Böylece hem pilates tanitılmakta hem de evde kendi pilates egzersizini yapmak isteyen kişiler için ya da antrenörler için bu kitaplar rehber olarak sunulmaktadır.

2 Joseph Pilates tarafından 20. yy başlarında bir fizik tedavi yöntemi olarak geliştirilmeye başlanan pilates, yoga, cimnastik ve diğer sporlardan egzersizleri bir araya getirerek merkezleme, konsantrasyon, kontrol, hassasiyet, akış ve nefes gibi noktalara odaklanarak bedensel zihinsel ve ruhsal bir rahatlama sağlamayı amaçlayan bir fiziksel aktivitedir (Caldwellet.al. 2009; Ungaro, 2002). 
Burada dikkat çekici bir nokta da pilates üzerine popüler kültür ürünlerinin önemli bir bölümü kadınları hedef alması ve kadınların yer aldığı görselleri kullanmasıdır (örn. Archer, 2004; Siler, 2000; Ungaro, 2002). Örneğin Amazon.com'da pilates üzerine en fazla satan kitaplar listesinin çok büyük bir bölümünde kadın görsellerinin yer aldığı kitaplar bulunmaktadir. (https://www.amazon.com/Best-Sellers-Books-Pilates/zgbs/books/282934 Erişim, 13.5.2019). Pilates pratikleri gerçekte kadın bedenine özgü egzersizler olmasa bile yüklenen toplumsal anlamlar nedeniyle erkeklerin pilates yapması öylesine sıra dışı bir şey olarak görülmektedir ki, "Erkekler için Pilates" (Pilates for Men) gibi kitaplar (Vigue, 2015) bile bulunmaktadır. Böylece hem bilimsel araştırmalar hem de popüler kültür kitapları, farkında olmadan pilatesi toplumsal cinsiyet düzeni bağlamında ancak "kadınlara uygun" bir egzersiz türü olarak kodlamış oluyor.

Connell'ın altını çizdiği üzere, toplumsal cinsiyet düzeni, çoklu kadınlıklar ve erkekliklerin rekabet ettiği, müzakere konusu olduğu, değişime uğradığı ve dinamik iktidar ilişkileri içinde kurulmasını içerir (1998). Ancak, toplumsal cinsiyetle ilişkilenen belli başlı kurumların, belirli örüntülerle genel anlamda "toplumsal cinsiyet düzeninden" farklılaşan "toplumsal cinsiyet rejimleri" bulunmaktadır (ss. 140-141). Bu bağlamda genellikle kadınlarla ilişkilendirilen bir egzersiz olan pilates yapılan salonlar da kendi özgül toplumsal cinsiyet ilişkileri bulunan alanlardır. Bu nedenle cinsiyetlendirilmiş mekânlar olarak pilates salonları, pilates ve erkeklik arasında kurulan ilişkileri anlamamız için son derece önemli bir alan sunmaktadır.

\section{Araştırmanın Arka Planı ve Metodolojisi}

Pilates yapan erkeklerin -kadınlara özgü olduğu düşünülen bir egzersiz olarak- pilatese yükledikleri anlamları ele alan bu araştırma, bu karşıtlığın altını çizen, ataerkil erkeklik kimliğiyle ve "erkeksiliğiyle" maruf bir kent olan Adana'da gerçekleştirildi (cf. Sungur, 2011). Kente ilişkin bu imge, son yıllardaki "Adanalı" (Güler ve Güneyer, 2008; 2010) ve "Sıfır Bir Adana" (Taşkın, 2016-2019) gibi Adana'daki erkeklik kültürünün sunulduğu diziler ile de pekiştirilmiştir. 
Adana' da pilates yapan erkekleri incelemek için niteliksel bir araştırma gerçekleştirilmiştir. Araştırmanın odağında en genci 42, en yaşlısı 74 yaşında olan ve yaş ortalaması 59 olan Adana'da bir tenis kulübünde pilates yapan altı erkek katılımcı bulunmaktadır. Ölçüt örneklem yöntemine göre belirlenen bu katılımcıların ilk ölçütü Adana'da pilates deneyimi olan erkeklerin saptanması olmuştur. Araştırma problemimizle yola koyulduğumuzda Adana'da görüşmeleri yaptı̆̆ımız tenis kulübü bünyesindeki pilates seansından başka neredeyse hiç erkek pilates grubu bulunmamaktaydı. Kulübün dişında şehir merkezindeki stüdyolarda bireysel olarak pilatese giden erkekleri bulmak oldukça güçtü. Bu nedenle araştırmanın ikinci yazarının bu pilates grubunun hocası olması bizim için oldukça değerli bir fırsat sunmuştur.

Araştırmaya en az üç ay pilates deneyimi olan kişiler katılmıştır. Yine görüşmecilerin neredeyse tamamı pilatese sağlık sorunları nedeniyle ya da sağlıklı kalma hallerini önemsedikleri için başlamıştır. Katılımcıların çoğu üniversite mezunudur. Bunların büyük bir bölümü de görüşmelerde öğrenildiği üzere üst sosyo-ekonomik düzeye mensup kimselerdir. Kat1lımcıların hepsinin daha öncesinde masa tenisi, rüzgâr sörfü, yüzme, basketbol, fitness, tekvando gibi spor dallarında spor geçmişleri bulunmaktadir.

Araştırmanın merkezini pilates yapan erkeklerle yapılan altı derinlemesine görüşme oluşturmaktadır. Bu görüşmelerin hepsi 45 dakikadan uzun sürmüştür. Görüşmelere veri doygunluğuna ulaşana kadar devam edilmiştir (Patton, 2014). Bu altı görüşme, grubun tamamına ilişkin veri sağlamıştır. Görüşmelerde yarı yapılandırılmış bir görüşme formu kullanılmıştır. Araştırmada katılımcılara pilatese başlamaya nasıl karar verdikleri, pilatesi sürdürme motivasyonları ve pilatesi nasıl değerlendirdikleri, katılımcıların çevrelerinin pilates yapıyor olmalarını nasıl değerlendirdiği ve katılımcıların pilates ve erkeklik ilişkisine ne gibi anlamlar yüklediklerine dair sorular sorulmuştur. Böylece Adana'da pilates yapan erkeklerin ataerkil erkeklikle ilişkisinin nasıl kurulduğu anlamaya çalışılmıştır.

Alan araştırmasının görüşmelerinin -Çukurova Üniversitesi Kampüsü'nde gerçekleştirilen biri hariç- tamamını makalenin ikinci ve üçüncü yazarı Adana'nın ünlü bir tenis kulübünde birlikte toplamıştır. 2018 Mart ayında verileri toplamaya başlanmış, Mayıs ayında ise veri toplama süreci 
son bulmuştur. Görüşmelerden önce, katılımcılara özel yaşamlarının gizliliğini koruyabilmek için, araştırmayı yazarken takma isimler verileceği belirtilmiştir.

Görüşmeler, pilates seansından önceki saatlerde planlandığı için seansa erken gelen grup üyelerinin dahil olmasiyla ya da pilates seanslarına gitmeyen, yalnızca tenis oynayan ve bu nedenle de katılımcılara "laf atan" kişilerle beraber zaman zaman dört-beş kişilik görüşmeler haline gelmiştir. Buradaki "laf atma" pratiği, araştırmamız için önemli bir veri kaynağı olmuştur. Çünkü bu kişiler görüşme sırasında araya girip "erkek adamın" pilatese değil tenise yönelmesi gerektiğini ima eden "şakalar" yapmışlardır. Katılımcıların bunlara verdiği yanıtlar ve anlık gerçekleşen bu olay döngüleri, erkekler arası toplumsal cinsiyet ilişkilerinin nasıl inşa edildiğinin gözlemlenmesine de katkı sağlamıştır.

\section{Hegemonik Erkeklik İnşasına "Yardımcı" Bir Egzersiz Olarak Pilates}

Araştırmada karşımıza çıkan temalardan ilki, pilatesin "yardımcı" bir egzersiz olarak görülmesiyle ilgilidir. Buradaki "yardımcı" ifadesi iki argümana göndermede bulunmaktadır. Bunlardan birincisi, pilatesin bağımsız bir spor ya da uğraşı olarak görülmemesini imlemektedir. İkincisi ise tenisin sağlıklı yaşamın taşıyıcı olarak ilişkilendirilmesine vurgu yapmaktadır. Pilatesin katılımciların anlam dünyasında "yardımcı" olarak kodlanmasının bu yönü, toplumsal cinsiyet ilişkileri ve erkek egemenliği için en elverişli stratejileri geliştiren erkeklik tipi olan hegemonik erkeklikle yakından ilişkilidir (cf. Connell, 2005, ss. 76-78). Zira toplumun spora ve erkeklerin yapması gerektiğine inandıkları spora dair oluşturduğu ataerkil normlar, katılımcıların pilatese yüklediği anlamları şekillendirmektedir. Pilates yapıyor olmak, pilates yapan erkeklerin anlam dünyasında, onları sürekli "muktedir" bir konuma yerleştirmekten ve "güçlü" erkekler haline getirmekten uzak görülmektedir. Böylece de pilates, hem halihazırda sürdürülen sporun hem de sağlıklı yaşamı sürdürmenin "yardımc1s1" olarak görülmektedir.

Görüşmeden elde ettiğimiz veriler, katılımcıların orta-üst sınıfa mensup, spor bilinci yüksek kişiler olduğunu gösteriyor. Bu bağlamda onların pilates deneyimleri, aslında Adana'da ünlü ve prestijli bir tenis kulübüne üyeliklerinin getirisi olarak yorumlanabilir. Çünkü katılımcıların tamamı 
bu tenis kulübüne yıllardır giden, kulüp bünyesinde pilates seanslarının açılmasıyla bu seansa kaydolan kişilerdir³:

"Hep arkadaşlarla birlikte dediler ki burada pilates açılacak biz tenis oynuyoruz ya taş gibi oluyoruz dediler ki gelin iyi olur onun için başladık yani." (Altan, 61 yaşında, emekli)

"Değişik bir spor olsun diye yani tenisten de sakatlanmamak için için uygun olacağını düşündüm ben ... Özellikle sakatlanmalara karşı koruyabilir diye düşünüyorum çalışmayan kasları çalıştırıyor." (Murat, 56 yaşında, jeoloji mühendisi)

Katılımcıların tenis kulübüne üye olmaları, onların pilatesi ayrı başına bir spor dalı olarak görmemelerinin ve ilgilendikleri asıl spor olan tenisin bir parçası olarak görmelerinin önemli bir nedenidir. Çünkü Altan'ın da "Vallahi benim için çok iyi, sporun bir parçası bence yani tenisin devamı gibi" sözleriyle ifade ettiği gibi, pilatesi ayrı başına bir spor dalı olarak değil de, bir performans sporu olarak gördükleri tenise destek olacak bir egzersiz olarak görmektedirler. Fakat kulüp üyeliği bağlamlarının d1şında, pilatesin niçin bağımsız bir spor olarak görülmediğini Tarık'ın aşağıdaki sözlerinden net bir biçimde çıkarabiliriz:

“... ama bizim Türkiye'de rekabet olmadan yapılan sporu hiç kimse seomez. İla bir sayı olacak ille bir çatışma olacak efendime söyleyeyim kendi kendine yapılan hiçbir sporu Türk halkın seveceğini zannetmiyorum...Erkeklerin sevmemesi bir rekabet olmadiğı için." (Tarık, 70 yaşında, diş hekimi)

Rekabetçilik günümüzün küresel kapitalist erkeklikleriyle ilişkilenen sosyo-tarihsel bir toplumsal cinsiyet özelliğidir (Kimmel, 2013). Pilatesin rekabetçilik içermemesi fakat erkek imgeleminde rekabet olması, pilates deneyiminin cinsiyetçi referanslardan beslenmesine yol açmaktadır. Tarık'ın Türk halkı olarak belirttiği, aslında erkek egemen bakış açısının sporu anlamlandırma biçimine işaret etmektedir. Nitekim Koca'nın (2006) da dikkat çektiği üzere, sportif etkinlik, üst düzey sportif performans, üstün fiziksel özellikler, yetenek, başarı, hırs ve rekorlar ile tanımlandıkça ve spor pratiği bu tanımların dışında kalanlara kısıtlamalar getirdikçe, biyolojik farklılıklar normalleştirilerek toplumsal ikincilleşmeye dönüşür. Ve bu dönüşümde belirleyici olan şeylerden biri erkek sporunun atletik deneyimin doğal biçimleri olarak varsayılmasıdır. Dolayısıyla spor ya da

3 Katılımcıların özel yaşamlarının gizliliğini korumak için metinde kullanılan isimler takma isimlerdir. 
egzersize yüklenen rekabetçi anlam, Murat'ın "yoksa pilates sıkıcı bir spor yani, tenise göre" sözlerinde karşılığını bulmaktadır. Böylece pilatesin ataerkil erkekliklerin bakış açısına göre nasıl anlamlandırıldığını görmekteyiz.

Erkekliği çatışma, sporu ise mücadele ve rekabet üzerinden tanımlama, hem sporu herkes için spor söyleminden uzaklaştırır hem de sporun erkeklerin alanı ve bir erkeklik pratiği olarak kodlamayı yeniden üretir. Böylece de sporu kadınların ve egemen olmayan, çeperde kalan kimliklerin deneyimlerinden uzaklaştıran anlamlara kapı aralar. Toplumun sporu mücadele ile erkekliği ise futbol ile tanımlaması, pilatesin toplum nezdinde, daha doğrusu ataerkil ilişkilerde, spor olarak görülmemesi ve erkeklere yakıştırılmaması sonucunu doğurmaktadır. Bir katılımcı bunu şöyle ifade etmiştir:

"Bu sporu yakıştırmıyor mesela. Tenisçi falan da yakıştırmadılar dediğim gibi. Benim çalıştı̆̆ım çevrede futboldan başka spor bilmiyorlar yani. Hatta bazen zaman kazanmak için iş yerinde giyinip geliyorum. Halı sahaya me gidiyorsun diyorlar bana. Yani spor deyince oradakilere, hal saha geliyor akıllarma; futbol geliyor." (Murat, 56, jeoloji mühendisi)

Bu bağlamda iki katılımcının aşağıdaki sözleri hem rekabet ve erkeklik ilişkisine hem de sporun heteroseksizm ve homofobi ile bağına oldukça açık ve güzel bir örnek teşkil etmektedir:

"Rekabet olan sporları erkeklere yakıştırır. Voleybol olur, basketbol olur tenis olur boks olur koşu olur. Ama bir rekabet olacak. Rekabet olmayan hiçbir şeyi yakıştırmıyor. Yoga gibi pilates gibi efendim işte dans da olabilir mesela. Baleyi de yakıştırmıyor. Ben kızlarımı küçükken baleye gönderdiğimde 30-35 kızdı bir tane erkek bulamazsını. Kimin oğluna dokuz on yaşında ya ne olur şunu getir baleye ver dediğinde, hiç kimse vermiyor."

Araştırmac1: Niçin baleye göndermek istemiyorlar sizce?

"Vallahi bu bale dediler, biraz onu yumuşak yapabilir, şey yapabilir dediler." (Tarık, 70 yaşında, diş hekimi)

"Hani biraz erkekler belki şeydir çatışmayı sever. Futbol da biraz çatışma üzerine mücadeleci bir spor olduğu için olabilir. Hani cimnastikte biraz daha estetik gerektiren böyle daha narin hareketlerin olduğu bir spor olması sebebiyle bence bale ve cimnastik bayanlara yönelik denebilir." (Ali, 42 yaşında, bankacı)

Kimmell'a (2013) göre homofobi, erkekliğin kültürel tanımını örgütleyen ataerkilliğin merkezinde yer alan ilkelerden biridir. Erkekler kadınsı 
ya da gerçek bir erkek olarak değil, gey olarak algılanma korkusu ile alaya alınmaktan korktuklarını; ancak kendileri de öteki erkekleri böyle değerlendirmekten kaçınmayarak dışlayıcı, baskıcı ve homofobik erkekliklerin inşa edilmesine katkıda bulunduklarına dikkat çeker. Dolayısıyla cinsiyetlendirilmiş sporun merkezindeki unsurlardan birinin homofobi olduğu anlaşılmaktadır. Bu durum, katılımcıların pilates deneyimlerini diğerlerine söyleyememelerine neden olmaktadır.

\section{Pilateste Sağlıklı Yaşam Söylemi, Yaşlanma Kaygıları ve Erkeklik Performansları}

Araştırmanın bulguları, görüştüğümüz erkeklerin, sağlıklı yaşam söylemi, yaşlanmaya bağlı olarak bedenin güçsüzleşeceği ve erkeklik performansının düşeceğine dair kaygılar gibi pek çok farklı nedenle pilatese başladıklarını ortaya koymaktadır.

(Pilatese başlattı̆̆ gruba ilişkin) "İşte bu grup var, hepsi ölmeye yakın insanlar, hepsi bir ayă̆̆ çukurda.Efendime söyleyeyim biri felç geçirmiş, öbürü ayağın kaldıramıyor. Onlara işte ne olur, Allah'ını severseniz gelin. Bak işte ileride, şimdi burada bazı pilates hareketleri ile titremeler oluyor ya... Bakın bu titremeler hoşunuza gidecek. Ki ileride zaten istemeden titreyeceksiniz. Onun için şimdiden titreyin o zaman o titremeleriniz daha geç olsun diye onları ikna ettim onun için geliyorlar (gülüyor)." (Tarık, 70 yaşında, diş hekimi)

Bu sözlerden pilatesin yaşlılıktan kaygılanan ya da yaşlanmalarını geciktirmek isteyen erkekler için bir tür kalkan işlevi taşıdığı anlaşılmaktadır. Yaşlanmaktan duyulan kaygı, katılımcının "titremeleriniz gecikir" ifadesinde somutlaşmaktadır. Dolayısıyla katılımcıların yaşlanmaktan doğan performans kaybını geciktirmek için pilatesi kullanmaları ataerkil bir erkeklik söyleminin yansımasıdır. Aşağıdaki iki alıntıda pilatesin vücuda kazandırdıklarının erkeklik performansı ile yakından ilişkili olduğunu bir kez daha görmekteyiz:

“Bizim yaşlılarımızı gördüğ̈̈müz zaman zaten Yani 65 yaşında hayatı bırakmış... Bu spor insanı genç tutacak 80 de 90 da ölüm her zaman var tabii ama yaşadiğı sürece kendini să̆lıklı tutabilecek bir spor." (Vahap, 50 yaşında, sigortacl)

"Mesela ben diyorum ki arabaya bindim arkaya bakacağım, lan şu hareket mesela (kafasını çevirip yan tarafa bakarak gösteriyor hareketi). Şimdi haftada 2-3 
gün şu hareketi yapmayan kimse arkasını dönüp arabanın arkasını göremiyor benim yaşıtlarım. Ben bugün bir yaşıtım ile karşılaşıtım yani adam neredeyse var ya baktım böyle hareketleri falan şey olmuş, artık kısıtlanmış yürüme falan." (Tarık, 70 yaşında, diş hekimi)

Araştırmanın bulguları, sağlıklı yaşam söyleminin ataerkil erkekliklerle iç içeliğine işaret ediyor. Nitekim Mortaş'in yaşlanma pratiğinin, bedenle nasıl "mücadeleye" dönüştüğünü tartıştığı çalışmasının izini sürdüğümüzde, erkek bedeninin ideal sınırının, sağlıklı yaşam etrafında şekillenen, düzenleyici ve yönlendirici söyleme uygun olarak çizildiğini görürüz (2009). Yazar, yaşlanma karşıtı söylemi, sağlıklı yaşam önerileri, bireylerin kendi bedenini koruma yollarına ilişkin öğretiler, kendi kendinin doktoru olma sanatı, uzun yaşamanın sırları ve genç kalma sanatı gibi son yıllarda gündelik hayatımızda sıkça karşılaştığımız öneriler bütününü kapsadığına dikkat çekmektedir (2009, s.174; Bozok, 2019). Dolayısıyla katılımcıların pilatesi sürdürme motivasyonu ve süresiz olarak bu pratiği sürdürme isteği, erkek bedeninin sağlıklı, güçlü, dinç olmasını salık veren hegemonik erkeklik değerlerini yansıtır. Pilatesin, yaşam tarzı önerilerinde en yaygın egzersiz biçimlerinden biri olarak sunulması (Sezgin, 2009) ve sağlıklı erkek olmanın hegemonik bir değer olması, bu araştırmanın katılımcıları açısından pilatesin sağlığın taşıyıcısı olarak niçin bu kadar önemli görüldüğünü açılayabilir.

Yukarıdaki alıntılarda da görüldüğü üzere, pilatesin bir anlamı sağlıkla ve yaşlanmaya karşı önlem almayla ilişkilidir. Bulgulardan, kimi zaman hareketsiz yaşamın ya da masa başa işlerinin kimi zaman ise yaşlanmaya bağlı olarak oluşan fiziksel ağrılardan -ya da hasarlardan- kurtulmak için doktor yönlendirmesi ile katılımcıların pilatese başladıklarını görmekteyiz. Örneğin Ali (42 yaşında, bankac1) boyun fıtığ1 teşhisi nedeniyle, Vahap ise vücudundaki kronik ağrılar nedeniyle pilatese başlamıştır:

Vallahi birkaç ağrıma iyi geldi şimdiden, daha da iyi olacă̆ını düşünüyorum. Yani şey biraz yani ben de omuz, ayak vücudumun farklı yerlerinde farkh ağrılar vardı ... Bir film falan çektik, ortada bir şey yok. Öyle bir şey yani romatizma mı diyeyim, ăgrilarım yaza doğru zaten normalde de rahatlıyorum ama birkaç ă̆rımdan burada iki ayda kurtuldum." (Vahap, 50 yaşında, sigortact)

Görüldüğü gibi katılımcılar için pilatesi sürdürmenin en önemli motivasyonlarından biri, pilatesin ortaya çıkış noktası olan sağlıkla ilişkilidir. 
Böylece sağlıklı yaşam ve pilates motivasyonu arasındaki ilişkinin nedenini anlamak kolaylaşmaktadır. Fakat bu katılımcının sözleri pilatesin cinsiyetlendirilmiş bir spor olarak kodlanmasının erkeklerin egzersiz deneyimlerini sınırlandırdığına işaret ettiği için Vahap'ın altını çizdiği nokta önemlidir. Vahap, sağlığını yitirmeden önce pilatese başlamak istese de daha öncelerde başlayamamasının nedenini aşağıdaki sözleriyle anlatmaktadır:

“Să̆lık sebebiyle başlamaya karar verdim ama iki üç yıl önce iyidir yani să̆lığın yerindeyken başlamak istediğim de başlayamadım. Vallahi erkek grubu bulamadım yani tanıdığım yerde yoktu diyelim... Ama hani bayanlara yönelik bir şey mantığı insanların kafasında var çok doğru bir mantık olarak görmüyorum ama yani." (Vahap, 50 yaşında, sigortacl)

Vahap, pilatesin kadınlara uygun görülen cinsiyetli yapısı nedeniyle, pilatese üç yil önce başlamak istese de erkeklere özel ya da karma grup seansları olmadığı için ancak başlayabildiğini vurgulamıştır. Bu sözler, toplumsal cinsiyet ilişkilerinin tek taraflı bir şekilde değil, ilişkisel sürdüğünü, tek yönlü değil çok taraflı kurulduğunu göstermekte. Burada erkeklerin kendilerinin de faydalandığı erkek iktidarının, bu iktidar kurulurken ya da yeniden üretilirken kendilerine de zarar verdiğini görmekteyiz. Pilateste erkeklerin alanın ötekisi olması ve ikincilleştirilmesi, erkek egemenliğinin erkeklere verdiği zararları yansıtmaktadır (cf. Goldberg, 2018).

\section{Pilateste Erkek Sosyalleşmesi}

Görüştüğümüz erkeklerin pilatesi sürdürme motivasyonunda, pilatesin sağlıklı yaşamla ilişkilendirilmiş olmasının yanı sıra, homososyal ortamlarından aldıkları keyfin de oldukça baskın olduğu görülmektedir. Katılımcılardan Altan (61 yaşında, emekli) bunu "Daha çok arkadaşlar yani arkadaşlarla beraber olmak" olarak ifade etmiştir. Murat (56 yaşında, jeoloji mühendisi) ise "Başlama grubumuz çok kafa dengi olduğu için bu yüzden başladık" diyerek pilates gruplarının "eğlenceli" yapısına vurgu yapmıştır. Diğer katılımcılar da pilatesin hem bedensel kazanımlarına hem de erkekler arası sosyalliklerinin keyif verici yanlarına dikkat çekmişlerdir. Örneğin bir katılımcı şu ifadeleri kullanmıştır: 
"Bir defa şöyle: pilatesi vücudumu ne kadar esnetirse esnesin iyi bir grup olmazsa yapmam mümkün değil. Yani eğlenceli geçirmiyorsam kesin bırakırım zaten eşim de söyledi 'iki ders gidersin üçüncüde bırakırsin' dedi. Grubun eğlenceli olması, arkadaşlarla pilatesten sonra keyif alacak vakit geçirmemiz, arkadaşlar arasında dayanışma, beraber seyahat etmemiz beraber eğlenceye gitmemiz falan bu hakikaten bizi bu spora çok bağladı mesela biz her Salı pilatesten sonra oturur şarap içeriz falan yani... Yani grubun iyi tarafı çok eğlenceli geçmesi, hiçbir lafi hakaret kabul etmemesi, onun üzerinden gülmemiz falan yani bütün şey bu. Yani grup hakikaten çok iyi, hepsi çok iyi" (Yılmaz, 74 yaşında, inşaat mühendisi)

Pilates seansının gruptaki diğer erkeklerle birlikte eğlenceli ve keyifli hâle geldiğini vurgulayan bu ifadelerden kadınların erkeklerin pilatesteki "gırgır şamatanın" dışında tahayyül edildiği görülmektedir. Bununla birlikte, katılımcılar kadınların girdiği birkaç seansa atıfta bulunarak, kadınlarla birlikteyken daha "ciddi" oldukların belirtmektedirler.

"Erkeklerle daha şamata oluyor da kadinlarla pek olmuyor bazen. Şakalarımız var onlar yapamiyoruz mesela. Ondan sonra daha ciddi yapıyoruz, bakıyorsun onlar yapıyor, sen Yapamadın mı olmuyor. Kötü hissediyorsun işte kadınlar daha esnek biz değiliz biraz da kıskanıyoruz herhalde" (Altan, 61 yaşında, emekli)

Ancak pilates hareketlerini yaparken kadınların o alanda olması erkekler arasında bir tür rekabet de doğurmaktadır. Altan'ın yukarıda alıntılanan sözleri bunun erkekliğin icra edilmesine dayalı bir rekabet olduğuna işaret etmektedir. Kadınların bir hareketi daha iyi yapabilmesi, erkeklerin kendilerini kötü hissetmelerine yol açmaktadır. Bu durum bir taraftan ikili cinsiyet tahayyülünde cinsiyetlerin karşıtlıklar ve hiyerarşiler üzerine kurulu olmasıyla, diğer yandan da hegemonik erkeklik açısından erkeklerin bir bütün olarak kadınlar üzerinde üstünlük kurmak istemesiyle ilişkilendirilebilir (cf. Connell, 1998). Araştırmanın katılımcılarının da pilatesi "kadın sporu" olarak görmeleri ve bu sıkıntılarla, kaygılarla başa çıkmaya çalışmaları, yakınlaşma nedeni sağlıyor olabilir. Çünkü erkeklerin kendi aralarında oluşturduğu bu "gırgır şamata" erkeklerin kaygılarından kaynaklanmaktadır.

Eleştirel erkeklik çalışmaları, homososyallik ile erkeklik arasında güçlü bağlar olduğunu savunur, ayrıca hegemonik erkekliğin bir sonucu olarak erkek birliği oluşturulmasında homososyalliğin etkili olduğu görülmüştür (Gedik, 2018). Örneğin Sancar (2013, s.18) erkeklerin homososyal “tek 
cinsli erkek cemaatlerinde" homofobik yönlendirmelerle sağaltıldığı "erkek eğlencelerinin" erkek egemenliğini inşa eden sosyal habituslar haline geldiğine dikkat çeker. Araştırmadaki pilates grubunun bu "gırgır şamatalarının" erkeklik iktidarını pekiştiren ve yeniden üreten böylesi "sosyal habituslar" olarak kurulduğunu öne sürebiliriz (Sancar, 2013, s. 18).

\section{Pilatesteki Erkeklik Söylemleri}

Görüşme bulguları, katılımcıların eşitlik fikrine yakın bir takım düşünceleri olsa da ağırlıklı olarak pilatese ve spora karşı oldukça stereotipik bakış açıları olduğunu ortaya koymaktadır. Fakat yine de bunların Adana'daki hâkim ataerkil bakış açısıyla kıyaslandığında çok daha olumlu bakış açısına sahip oldukları anlaşılmaktadır. Çünkü, katılımcıların deneyimleri açısından düşünüldüğünde, Adanalıların pilates yapan erkeğe bakış açısı şu şekildedir:

"(Adana halkı) Yani abuk bakar herhalde (gülüyor). Sen de mi dansöz oldun derler (gülüyor)." (Vahap, 50 yaşında, sigortacl)

"Yani bu pek erkek işi değil, bu sizi bozar ne işiniz var, bundan ne zevk alıyorsunuz." (Tarık, 70, diş hekimi)

"Halk arasinda öyle bir şey var. Nerden buldun bu sporu ya diyen var. Şey bile düşünebilirler yani bu yumuşamış bir erkekmiş gibi düşünebilirler yani benim bulunduğum çeoremde...Nasıl söylesem...Bunu kimse kabul etmez." (Murat, 56 yaşında, jeoloji mühendisi)

“Toplum yani erkeklerin çoğu bu ne ya kız sporu diyorlar, dalga geçiyorlar. Bu yapılır mı, bu ne kız sporu gibi şeyler diyorlar. Gel şurada doğru düzgün bir şeyler yap boks yap güreş yap diyorlar ama ben de tersine bunun faydah olduğuna inanıyorum... (Adana halkı pilates yapan erkeğe) Valla nonoş derler hep bunlar cahillikten geliyor." (Altan, 61 yaşında, emekli)

Yukarıdaki alıntılardan, cinsiyetçi ve homofobik/transfobik söylemlerin, katılımcıların spor tercihleri ve deneyimlerini itibarsızlaştırdığını görmekteyiz. Nitekim tenis kulübündeki, çoğunlukla yüksek sosyo-ekonomik sınıf ve eğitimli erkeklerin de bu itibarsızlaştırmayı sürdürdüklerini, hatta zaman zaman onları pilates deneyimlerinden caydırmaya çalışmaktadırlar: 
"İşte burada (kulüp) arkadaşlarımız var bunların da bazıları, tepkililer. Gel tenis oynayalım pilateste ne var iki dakika elini kaldırn indiriyorsun bir faydası da olmaz sana, falan diyorlar." (Altan, 61 yaşında, emekli)

Pilates katılımcılardaki, "erkekliğin kaybına" yönelik bir korkuyu tetiklemektedir. Bu da bir tür erkeklik kaybı olarak erkeklik krizini karşımıza çıkarmaktadır. Pilatesteki hareketlerin erkeklerin yararına olmadığı, hatta erkekliğe zarar vereceğine dair duyulan korku ise katılımcların çoğunlukla bir tür "sağlık" vurgusuyla uyarılmasına yol açmaktadır:

"(Kulüpte pilates yapmayan arkadaşları) Bazısı laf atıyor ne zaman sakatlanacaksın diyenler var yani. (Gülüyor). Birkaç kişi sakatlanmış bazı hareketlerin erkeklere karşı çok şey olmadığını düşünenler var ... İşte bu fitık olayı şudur budur. Bundan dolayı bence, ben öyle düşünüyorum ya bir bayan fitık olacağım kaygısıyla pilates yapmıyordur yani ben öyle anlıyorum. Yani o fitıktır şudur budur erkeklikle alakalı bir kaygıdır. Aslında bir bayan pilates yaparken ben ne zaman fitık olacağım diye düşünmüyordur mesela." (Vahap, 50 yaşında, sigortacl)

Hegemonik erkekliğin kadınlar üzerindeki kontrol ve egemenlikten çok diğer erkekler üzerindeki egemenliğine (Donaldson, 1993) 1şık tutan bu uyarıların, erkekliğin kaybedilmemesi, sınırlarının ihlal edilmemesi için oluşturulduğu anlaşılmaktadır. Erkek egemenliğinin cinsel iktidar temelinde kurulması, pilates deneyiminin fitığa, yani erkek cinsel iktidarına zarar getireceği söylemiyle bütünleşerek, katılımcıların kadınlar için uygun görülen bir alan olarak pilatesten uzaklaştırılmaya çalıştıklarını göstermektedir. Bu bağlamda kurulan "erkek cinsel gücüne" sahip olmak da önemli bir erkeklik değeri olarak görülmektedir (cf. Sancar, 2013, s.156).

Adanalıların ve tenis kulübünde pilates seanslarına katılmayan diğer erkeklerin yanı sıra zaman zaman katılımcıların kendilerinin de homofobik söylemleri olduğu dikkat çekicidir. Örneğin yoga yapan erkeklerin "çoğu sporu becerememiş, homoseksüel tipler" olarak görülmesi ve deniz kızı hareketini yaparken kendilerini "kadınsı" hissetmeleri katılımcı erkekler arasındaki pilatese yönelik homofobik tutumları yansıtmaktadır. Öyle ki katılımcılardan Tarık şöyle demiştir:

"Yani çoğu sporu becerememiş mesela yogaya gelen erkekler var böyle içine kapanı efendime söyleyeyim başka dışa dönük olmayan böyle hafif şey böyle böyle şey homoseksüel tipler. E tabii onlar öyle olunca halk öyle görüyor." (Tarık, 70 yaşında, diş hekimi)

Benzer bir biçimde katılımcılardan Murat da şu ifadeleri kullanmıştır: 
“Deniz Kızı'n yapamıyorum ben ya (gülüyor). Ya benim dizlerimde biraz problem var tam bükülmüyor o yüzden bence yapamıyorum ya ama ona da faydası oldu ya başladıktan sonra"

Araştırmac1: Nasil hissediyorsunuz o hareketi yaparken?

"Yani kadınsı gibi deyim o kadar geliyor aklıma" (Murat, 56 yaşında, jeoloji mühendisi)

Vahap ise kadınlıkla esnekliği ilişkilendirerek şöyle demiştir:

"Biraz kapanmalar var deniz kızı falan onlar bana biraz ağır geliyor... biraz zor geliyor yani erkeksi hareket değil. Biraz daha esneklik istiyor, o esneklik bayanlarda doğal olarak var. Yani bayan vücudu olarak en katı vücut bir erkek vücudundan daha esnektir. Yani bizde o esneklik o kadar fazla yok fazla hareketler öyle şey yapabilir. Biz aramızda zaten çok şey yapıyoruz, işte bu hareket fittk eden hareketler falan söyleniyoruz (gülüyor)." (Vahap, 50 yaşında, sigortacı)

Bu ifadelerden de görüldüğü üzere, katılımcıların kimi pilates hareketlerini "erkeksi hareketler" ve "kadınsı hareketler" olarak değerlendirmeleri, homofobik tutumlar aracilığıyla yeniden üretilen ataerkil erkeklik kodlarını yansitmaktadır.

Araştırmanın önemli bulgularından biri de, görüşmeler esnasında konuşmaya dişarıdan dahil olan Haluk'un (76, sanayici) sözlerinde karş1mıza çıkmaktadır. Haluk'a göre, pilates "erkekliği bozmaz" fakat zaman zaman pilates seanslarının içine serpiştirilen zumba hareketleri "erkekliği bozar". Haluk bunun nedenini: "Zumbada göbek atyorum ben. Kime sorduysam "aaaa o göbek atma" dedi" şeklindeki sözleriyle açıkladı. Bu sözlerden hangi sporların erkekliğin kurucu öğelerini pekiştirdiğini, hangilerinin ise erkekliğin kültürel ideali için sakıncalı olarak düşünüldüğü bir kez daha görülmektedir. Ataerkil değerlerin ve cinsiyetçi rejimin hâkim özelliklerini taşıyan Adana'da erkeklerin göbek atması ya da dans etmesi, "delikanlılı̆̆ı bozan" bir hadise olarak addedilir (Kavasoğlu, Rençbereli ve Yenel, 2017). Selek'e (2013) göre ise, Türkiye coğrafyası için erkeklik kalıplarını toplumsallaştıran ritüeller, erkeklere kadınsı özellikler göstermemelerini dikte etmenin de içinde olduğu erkeklik kurgusunu pek çok farklı biçimde ve farklı mekanizmalarla kurar (s. 227). Dolayısıyla bu ataerkil toplumsal yapılardan ve sosyalizasyon süreçlerinden geçerek "erkekleşen" katılımcılar, pilateste var olurken bu kimliklerden azade olmaksızın ataerkil erkekliği inşa etmektedirler. 
Burada, katılımcıların pilates yaşantılarını, sosyal çevrelerindeki insanlara karşı nasıl açıkladıkları, diğer bir anlatımda pilates alanında var olma stratejilerinin neler olduğu da ortaya çıkmıştır. Görüştüğümüz erkekler, pilatesin hiç de öyle "dışarıdan" görüldüğü gibi kolay bir spor olmadığını vurgulamışlardır. Bu vurguyu yaparken bazı hareketlerin kendilerini zorladığını ve tam da bu nedenle herkesin, yani tüm erkeklerin, pilatesi kolaylıkla yapamayacağını ileri sürmeleri, performatif erkeklikle ilişkili görülmektedir:

"Sanki kız sporuymuş gibi görüyorlar (pilatesi). Tabii içine girmedikleri için dışarıdan öyle görüyorlar... Valla gelin sizde yapın diyorum, ondan sonra görüşelim." (Altan, 61, Emekli)

"Dışarıdan göründüğ̈̈nde çok kolay ama kendileri geldikleri zaman, bir kere bile olsa, yarm kere bile olsa her geldiklerinde perişan oluyorlar. Mesela Akın abi (83, İsletmeci) vardı geldiğinde dersi bitiremedi her yerinden ter fışkırdı, sıkıntılı hareketler ya." (Tarık, 70 yaşında, diş hekimi)

$\mathrm{Bu}$ ifadelerde, katılımcıların kendilerini marjinalleştirmeye çalışan hâkim erkeklik söylemlerine alttan alta meydan okuduklarını anlıyoruz. Çünkü her iki katılımcı da, pilateste de bedensel güce dair zorluklar olduğunun mesajlarını vermektedir. Görüşülen pilates yapan erkekler, sosyal çevrelerinden aldıkları cinsiyetçi söylemlere karşı mücadele stratejisi geliştirirken, "gelin siz de yapın", "görüşelim" gibi fiziksel meydan okumalarda bulunmaktadırlar. Bu durum pilatesteki ataerkil erkekler arası iktidar ilişkilerinin nasıl kurulduğunun ve grup içinde yeniden üretildiğinin bir göstergesidir. Bunun sonucunda, bazı katılımcılar çevrelerine karşı pilates deneyimlerini gizli tutmakta, pilates kursuna gittiklerini söylememeyi tercih etmektedirler.

Kavasoğlu ve Yaşar (2016), "toplumsal cinsiyet normlarının dışındaki" kadın ve sporcuların deneyimlerini analiz ettikleri araştırmada, kadınların aksine erkek sporcuların buz pateni, dans, cimnastik gibi kadınlara özgü olarak algılanan spor dallarında, elde etmiş oldukları başarıların, onların sosyal statülerinde pek bir değişiklik yaratmadığını ve onlara yönelik toplumsal cinsiyet baskısının devam ettiğini kaydetmektedirler. Benzer bir durum pilates için de geçerlidir. Bu durum ataerkil erkekliklerin, egemenlik alanlarını "erkekliği koruyarak" ve onu denetim altına alarak sürdürmesiyle ilişkilidir. Zira pilates deneyimin gizlenmek istenmesi, 
hâkim toplumsal cinsiyet rejiminin, ataerkil cinsiyetçi ve homofobik kalelerle kurulu olmasının bir sonucudur. Böylesi tepkiler, ataerkilliğin çok yönlü, çok taraflı ve çok katmanlı bir biçimde kuruluyor ve deneyimleniyor olmasinı yansitmaktadır.

\section{Bu Yaştan Sonra Pilates “Erkekliği Bozsa N'olur": Pilates Erkeklik Krizine Yol Açar Mr?}

Araştırmanın katılımcılarının kırk yaş ve üzeri erkekler olması, onların kendilerine yönelik ataerkil ve cinsiyetçi söylemlere verdikleri cevaplara yansımaktadır. Katılımcıların neredeyse tamamı bu söylem ve pratiklerle, yine erkeklik iktidarının kurucu öğelerinden olan cinsel iktidara gönderme yaparak, savunma mekanizması geliştirmektedir. Örneğin, pilates için "bu saatten sonra erkekliği bozsa ne olur" söylemi, erkekler arasındaki hiyerarşik iktidar ilişkilerinin nasıl sürdürüldüğü ve yeniden üretildiğini göstermektedir. Böylece genç ve yaşlı erkekler arasında, ataerkil erkeklik hiyerarşilerinin merkezinde olmak ve bu çemberin çeperinde olmak gibi bir anlam söz konusudur. Başka bir anlatımla, görüştüğümüz erkekler için, yaşlanmayla birlikte erkek egemenliğinin merkezinden çeperlerine doğru itilmeye ilişkin kaygılar söz konusudur. Görüşmeler, katılımcı erkeklerin, performans kaygılarının yanı sıra yaşlılıkla birlikte erkekliklerini "kaybedeceklerine" yönelik kaygıları bulunduğunu ortaya koymaktadır. Dolayısıyla görüşülen erkeklerin yaşlanmaları krizin başat yönlerinden biridir. Bu konuda görüşmelerin yapıldığı tenis kulübünde araştırmacıların başından geçen bir olay dikkat çekicidir.

Katılımcılardan Y1lmaz (74 yaşında, inşaat mühendisi) ile görüşmemizin sonlarına doğru -biri pilates seansına da katılan-tenis kulübünden iki arkadaşının, sohbetimize dahil olmasıyla şekillenen bir olay döngüsü yaşanmıştır. Görüşmeler devam ederken pilates yapmayan bir kulüp üyesi olan Mustafa (65 yaşında, avukat) yanımıza geldi ve "Haluk Bey hadi gelin tenise!" dedi. Haluk "Yok ben pilates yapacağım" diyerek yanit verdi. Hemen ardından Mustafa kararlı ve biraz da sitemkâr bir ses tonuyla "Ben pilatese gelmem ya." dedi. Bu esnada grubun pilates eğitmenliğini yapan araştırmacı, Mustafa'ya "Pilates yaptınız mı daha önce?" diye sordu. Mustafa ise araştırma için önemli ifadeler içeren şu yanıtı verdi: "Pilates bana çok hafif geliyor ya. Ben günde altı saat tenis oynayan bir adamım. Pilates 
falan bana uzak, yoga falan bana biraz şey gibi geliyor yani yaşlılar için bir şey ya da bayanlar için... Pilates delikanlıyı bozar abi (gülerek)". Tam bu esnada daha derinlemesine bilgi edinme çabasında olan diğer araştırmacı "Neden böyle olduğunu düşünüyorsunuz, bize biraz açılar mısınız?" sözleriyle konuşmaya dahil oldu. Mustafa söylediklerini tekrar ederek ve Haluk'a bakmaya devam ederek "Delikanlıyı bozar abi ben sana ne dedim bozar dedim bak tenis oynayamiyorsun (gülüyor). Hadi size kolay gelsin." Bu sırada tam giderken geri döndü ve: "Yanlış anlamayın kızlar yani şaka yapıyorum. Spor değil aslında pilates de yani. Pilates spor değil. Burada anlaşalım. Pilates adaleleri germek ve dinlendirici bir şey. Abi pilates delikanlıyı bozar yapma bunu sen (gülüyor ve gidiyor)" sözleriyle konuşmasını tamamladı. Mustafa'nın gitmesiyle birlikte Yılmaz'ın ağzından şu cümleler döküldü: "Sporun erkeklikle yani bizimle ne alakası var. Bozulacaksa bu yaştan sonra bozulsun. En yanlış adama sormuşsunuz o kafayı erkeklikle bozmuş manyak."

Hegemonik erkeklik, ataerkil yapının belirli biçimlerde kurumsallaşması, kadınların ve diğer erkeklerin kontrol edilmesi, onlar üzerindeki iktidar ile dolaşıma girer (Connell, 1998). Yukarıdaki olay, hegemonik erkekliğin spor yoluyla nasıl kurulduğunu; bu kurguda kadınları ve "yaşlı" erkekleri nasıl dışladığını rahatlıkla görebiliriz. Yukarıdaki olay döngüsünden de anlaşıldığı gibi, Adana'da görüşmelerin yapıldığı tenis kulübünde, "yaşlı erkekler" marjinalleştirilen ve aynı zamanda krize sürüklenen erkekler olarak karşımıza çıkmaktadır. Bu noktada Özbay (2013, s. 191), yaşlı erkekler ve onların "iktidarsız" bulunan hayatlarının da kaçınılmaz olarak marjinalleştirildiğinden bahsederek, hegemonik erkekliğin "yaşlı erkeklikler" üzerine kurulmadığının altını çizer. Sancar ise, erkeklikler arasındaki güç mücadelesine baktığımızda genç ve yaşlı erkek olmak arasında hiyerarşik bir iktidar ilişkisi kurulduğunu ortaya koymaktadir (Sancar, 2009, s.186).

Bulgular, görüşülen erkeklerin, daha genç yaşta pilatese başlamaları ve o yaşlarda çevrelerinden ataerkil yorumlar almaları takdirde, erkeklik üreten söylem ve davranışlarda olacağını ortaya koymaktadır. Bununla birlikte, yaşlanmalarıyla, yaşlanmaya yükledikleri anlamlarla birlikte erkeklikleri üzerinden yapılan iğnelemelere kulak asmayacaklarına da işaret etmektedir. 
"O zaman gençtim belki yapamazdım. Yani şeye de kapılırdım o tepkilere belki cevap da veremezdim yani yapmak istediğim bir sporda belki uzaklaşacaktım hiç yapmayacaktım belki etki altında kalabilirdim. Yani şimdi bana kim ne derse desin 2020 yılında olacağımız için söylemiyorum, şu anda benim bakışımla ne söylerse söylesin yani o kendini şey yapar, o beni bağlamaz. Ama o dönemde etkilenebilirdim ondan diyorum şunu söyleyeyim gençlere bu sporu iyi anlatmak lazım yani başlasalar ömür boyu yapacakları sporun yanında da bir spor." (Vahap, 50 yaşı̇nda, sigortacı)

“(20'li-30'lu yaşlar) O zaman belki biraz daha alıngan olabilirdim şimdi biraz yaşın vermiş olduğu değişik bir şey var, olgunluk var. O zamanlarda insan daha alıngan olabilir genç yaşta daha değişik tepki verebilirdim mesela." (Murat, 56 yaşında, jeoloji mühendisi)

$\mathrm{Bu}$ ifadelerden, katılımcların spora ve bedene yükledikleri anlamların yaşla birlikte değiştiğini görmekteyiz. Bu düşünceler yaşla birlikte "rekabetçi" spordan "sağlık için" spora doğru değişim göstermektedir. Rekabetçilik, daha çok genç olanlarla ilişkilendiği için burada yaşlanma da etkili olmaktadır. Bununla birlikte görüşmeler, yaşlanmayla birlikte "iktidar kaybı" olduğuna ve bunun dişavurumumun değişik gerekçelendirmelerle ortaya çıktığına işaret etmektedir.

Bunun yanı sıra katılımcılar geçmiş yıllarda, cinsiyetlendirilmiş sporları ve pilates yapamıyor oluşlarını, toplumsal yaşamın dönüştügünü ve buna bağlı olarak da erkeklik tanımlarının değiştiğini belirtmişlerdir. $\mathrm{Bu}$ durum, onların değişimi söylemsel olarak öngördüğünü ortaya koymaktadir:

“90’lı yillarda 2000'li yillarda bu bakış açıları çok daha farklıydı ve bu spor hiç bilinen bir spor değildi. O zaman bırakın pilatesicimnastik bile tuhaf geliyordu insanlara. Yani bayanların yaptı̆̆ı bir spordu. Erkeklere cimnastik dendiğgi zaman tuhaf geliyordu. Bakın cimnastik şu an hiç kimseye tuhaf gelmiyor doğru mu ama doksanlı yıllarda cimnastik çok şey değildi yani." (Vahap, 50, sigortacı)

"(Eskiden pilates) Hem bu kadar bilinmiyordu hem de o zamanlar şey var mıydı ya Ebru Şallı çok yapardı pilatesi, belki ordan bayan sporu gibi bir yorum gelebilirdi." (Ali, 42 yaşında, bankacı)

Yukarıdaki ifadeler, erkekliklerin tarihsel ve toplumsal inşalar oluşunu ortaya koymaktadır. Dolayısıyla tıpkı kadınların hizaya sokulması gibi, erkeklerin de farklı toplumsal ilişkilerde ortaya çıkan "özgün araçlarla ve çeşitli ritüellerle "adam edildiği" anlaşılmaktadır (cf. Selek, 2013, s.221). 
Yılmaz'ın ifadelerinden anladığımız kadarıyla bu "adam etme" çabası, kadınsılıktan uzaklaşmak için yeniden ürettiği erkeklik ritüelleri, bir erkeğin ömrü boyunca devam etmektedir:

"Hoş vakit geçiriyoruz, gayet güzel, hocamız iyi, arkadaşlar keyifli. Yapabildiğimiz kadarını yapıyoruz işte. Her hareketi yapacaz diye bir şey yok zaten, kimimiz eftelyayı iyi yapıyor (gülüyor) kimimiz kız hareketi diye yapmıyor. Şimdi kulüpte zaten her pilatese gidişimizde 'ya bu erkekliği bozar' diyorlar (gülüyor). 70'ten sonra bozulsa n'olur bozulmasa (gülüyor) sen gençsin başlama diyoruz (kahkaha atıyor) bu ciddi değil zaten onlar bize takılıyor biz de onlara takılıyoruz." (Yılmaz, 74 yaşında, inşaat mühendisi)

Yılmaz'ın "takılma" olarak nitelendirdiği bu durum, pilates seansındaki erkeklerin de erkeklerin iktidarlarının kaybolmasına hem performans olarak hem fiziksel olarak uzaklaştığını düşündüklerini göstermektedir.

Bununla birlikte, başka bir katılımcı olan Ali'nin sözleri ise bize-diğer erkek arkadaşlarına rol model olma, onları da pilatese yönlendirme gibi yollarla- "başka erkeklik de mümkün olabilir" demek için güzel bir fırsat sunmakta ve değişimin nasıl mümkün olabileceğini tartışmamızı sağlamaktadır. Bu ifadeler, bir katılımcı erkeğin bile arkadaşlarını pilatese yönlendirmesiyle, bu egzersizi yapan erkekler arasında cinsiyetlendirilmiş bir spor olan pilates üzerine önyargıların adım adım kırılmaya başlayabildiğini göstermektedir. Pilates deneyimi olan bu erkeklerin varlığı, hem farklı erkekliklere hem de erkekliğin dönüşüm içinde olan dinamik yapısina işık tutmaktadır.

“...Mesela ben hiç futbol maçı izlemem. Hiç seumem yani izlemeyi... İş arkadaşımı da ben yönlendirdim. Onun da belde boyunda ă̆rı vardı, sen de gel dedim, beraber gidelim dedim. Öyle ertesi hafta başladık hemen" (Ali, 42 yaşında, bankacl)

Bu katılımc1, günümüzde birçok toplumda erkekliğin kurucu imajlarından birini oluşturan, çatışma ve sertlikle bezenen futbolu hiç sevmediğini dile getirmiştir. Bu durum, onun pilatese başlamasını ve sonrasında da iş arkadaşlarını bu egzersize dahil etmesinin önünü açmıştır. Connell, toplumsal cinsiyete dayalı iş bölümü, iktidar ilişkileri, duygusal ilişkiler ve simgeselliğin değişiminin erkeklik tanımlarını da değiştirdiğini söyler ve bunları ataerkil yapılar olarak görür $(1998 ; 2000)$. Bu bağlamda yukarıdaki örnekte de görüldüğü gibi, pilatese cinsiyetçi anlamlar yüklemeyen 
erkekler, aileler ve akrabalar vardır. Bu yeni ilişki türleri, modern yaşam tarzlarının ürettiği söylemler, erkekliğin değişen, değişmekte olan hallerini imlemektedir. Fakat bu değişimin erkeklere ne derece özgürlük getirdiği, ne gibi yeni tahakküm mekanizmaları kurduğu bu araştırmanın s1nırlarını aşmakta ve yeni araştırmalar için kapı aralamaktadır. Bu bağlamda Türker'in "Erkeğin özgürlüğü, erkin her türünü sorgulayarak başlar. Erkin her türlü uygulamasından feragat edebildiği ölçüde özgürleşir erkek" (2004, s.9) şeklinde ifade ettiği üzere, erkekler ve erkekliklerin özgürleşmesinin şifrelerinden biri, hâkim ataerkil cinsiyet kodlarının sorgulanmasından geçmektedir.

\section{Sonuç}

Adana'da erkeklerin cinsiyetlendirilmiş ve neredeyse tamamıyla kadınlarla ilişkilendirilen egzersiz olarak inşa edilen pilatesteki deneyimlerini ve pilatese yükledikleri anlamları inceleyen bu araştırma, pilates yapan erkeklerin farklı söylem ve pratiklilerle, ataerkil erkeklik kodlarını yeniden ürettiğini ortaya koymuştur. Pilatesin bağımsız bir egzersiz türü olarak değerlendirilmemesi ve bu şekilde deneyimlenmemesi, spora yüklenen rekabetçi anlamla yakından ilişkilidir. Rekabetçilik ise, erkek kimliğinin en baskın tarihsel ve kültürel özelliklerinden biridir. Bu durum pilatesin, rekabetçilik içermemesi nedeniyle, ataerkil bir bakış açısıyla zaman zaman "sıkıcı" olarak değerlendirilmesine yol açmaktadır.

Diğer yandan, katılımcılar için yaşlanmaya bağlı olarak bedenlerinin güçsüzleşeceği ve erkeklik performansının düşeceğine dair kaygılarının olduğu anlaşılmaktadır. Bunun sonucunda pilatesi, süresiz bir biçimde devam ettirmek istemektedirler. Araştırmanın ilgi çekici bir bulgusu ise, görüştüğümüz erkeklerin bazılarının pilatese, daha önce başlamak istemelerine rağmen, kendileri için pilates seanslarına ulaşamamalarıdır. $\mathrm{Bu}$ durum, sporun cinsiyetlendirilmesinin erkekleri pilatesin ötekisi hâline getirdiğinin göstergelerinden biridir.

Pilatese yönelik "erkek adam pilates yapar mı", "ne işiniz var", "fıtık olacaksınız" gibi ataerkil söylemlerin özellikle tenis kulübündeki ya da sosyal çevrelerindeki diğer erkeklerden geldiği anlaşılmaktadır. Ve katılımcıların bunlarla çoğunlukla fiziksel bir meydan okuma ile karşılık ver- 
diği görülmektedir. Bu durum görüşülen Adana'lı erkeklerin ataerkil erkeklik pratiklerine bir örnektir. Dahası katılımcıların kendilerinin de homofobik söylemleri bulunmaktadır.

Araştırmanın sonuçları, görüşülen erkeklerin kendi aralarında, pilates seanslarda oluşturduğu homososyal erkeklik ilişkilerinin bir erkeklik alt kültürü oluşturacak şekilde kurulduğuna işaret etmektedir. Pilates gruplarının "eğlenceli" olarak nitelendirilmesi, bazı hareketleri yaparken ya da bazı hareketleri yapamazken birbirleriyle dalga geçmeleri, ataerkil erkeklik söylem ve pratiklerini yansıtmaktadır. Son olarak, pilatesin yaşlı erkekler ve kadınlar için uygun olduğunun düşünülmesi, pilatesteki erkekleri marjinalleştirmekte ve onları bir tür krize sürüklemektedir. Buna karşın, ataerkil niteliğiyle öne çıkan bir şehir olan Adana' da erkeklerin kadınlıkla ilişkilendirilen bir egzersiz olan pilates yapıyor olmaları bile cinsiyetlendirilmiş bir egzersizin hakim ataerkil toplumsal cinsiyet ilişkilerini değiştirmese de esnetme potansiyelini ortaya koymaktadır. 


\title{
EXTENDED ABSTRACT
}

\section{On The Borders of A Gendered Exercise: Pilates Experiences of Men in Adana}

\author{
$*$
}

\author{
Mehmet Bozok - Z. Merve Munar - İrem Kavasoğlu \\ Maltepe University, Çukurova University, Çukurova University
}

This study examines Pilates as a gendered exercise focusing on men doing this exercise in Adana. Pilates is considered as a socially inappropriate exercise for male identity and patriarchal masculinities (Markula, 2006; Messner, 2000). In this context, our aim in this article is firstly examining the pilates experiences of educated and middle-class men who attend to the tennis club in Adana, a city known for patriarchal masculinities in Turkey. And secondly, we aim to investigate the meanings they attribute to pilates, which is built as a gendered exercise, coded peculiar to women.

As McKay, Messner, and Sabo (2000) point out, critical studies on men and masculinities should take a feminist and anti-sexist stance when considering the relations between sports and masculinities. One of the most important emphasis of this theoretical position is related to the criticism of dominant constructions of masculinity. As Connell and Messerschmidt pointed out, today's image of hegemonic masculinity plays an important role in the construction of well-groomed and healthy looks, and regularly engaged in sports and physical activity (2005, pp. 833-835). Sports and exercise, as Parker points out, are one of the tools used by men in achieving the goals such as "looking good" and "feeling good" in trying to achieve the hegemonic ideals of the male body in today's consumer societies (1997, pp. 130-131). In this context, contemporary trendy activities such as pilates, is among the practices that men use to try to achieve a healthy, handsome and fit body image, in the context of the hegemonic upper and upper middle class ideals of hegemonic masculinity.

In this study, in-depth interviews were conducted with six men doing pilates using qualitative method. The collected data were analyzed by content analysis method. The focus of the research is on six male participants practicing pilates in a tennis club in Adana, of whom the youngest was 42 and of whom the oldest was 74 . The center of the study consists of six in- 
depth interviews with men doing pilates. A semi-structured interview form was used in the interviews. In the study, participants were asked questions about how they decided to start pilates, their motivation to practice pilates, and how they evaluated pilates, how they evaluated their environment for practicing pilates, and what meanings they attributed to the relationship between their experiences about pilates and masculinity.

The first of the themes that we encounter in the research is that pilates is seen as an "supportive" exercise. The term "supportive" here refers to two points: Firstly, it signifies that pilates is not seen as an independent sport or pursuit. Secondly, it emphasizes the association of tennis as a carrier of healthy living. Thus, Pilates is seen as the "supportive" of both the current sports and the maintenance of a healthy life. Since the participants are members of the tennis club is an important reason for considering pilates as a supportive sport for the main sport they are interested in. However, pilates is seen as far from making them "always able" and "strong" men.

The findings of the study reveal that the men we interviewed started pilates for different reasons such as the healthy life discourse, concerns that the body will become weak due to aging and their masculinity performance will decrease. As it can be seen, one of the most important motivations for the participants to continue pilates is achieving the goal of healthy life, which is the origin of pilates itself.

In the motivation of the men we interviewed, it is seen that pilates is associated with the idea of healthy life, and the pleasure they enjoy from their homosocial environment practicing pilates is quite pivotal. Stating that the pilates session has become fun and enjoyable with other men in the group, it can be seen that women are imagined outside the "razzledazzle" of men in pilates.

Findings show that although the participants have some ideas close to the idea of equality, they have quite stereotypical perspectives towards pilates and sports. Pilates triggers a fear of the loss of masculinity amongst the participants. This brings us to the crisis of masculinity as a loss of masculinity.

Almost all of the participants present a defense mechanism by referring to sexual power, a constituent element of masculinity, through these discourses and practices. For example, for pilates, the discourse of "what if it 
harms masculinity after this age" shows the hierarchical power relations amongst men are maintained and reproduced. Therefore, we see that the meanings attributed by the participants to the sport and body change with age.

This study shows that the motivation of participating men to start and maintain pilates is intertwined with the effort to maintain healthy lifestyle discourse and masculine performance and that the participants' own discourse and practices of masculinity are prominent in their pilates experience. As a result, it is seen that the patriarchal masculinity codes of the participating males doing pilates in Adana also spread to the meanings they impose on this exercise.

\section{Kaynakça / References}

Adams, A. (2011). Josh wears pink cleats: Inclusive masculinity on the soccer field. Journal Of Homosexuality, 58(5), 579-596.

Aibar-Almazán, A.,Hita-Contreras, F., Cruz-Díaz, D., de la Torre-Cruz, M., Jiménez-García, J. D. ve Martínez-Amat, A. (2019). effects of pilates training on sleep quality, anxiety, depression and fatigue in postmenopausal women: A randomized controlled trial. Maturitas, 124, $62-$ 67.

Anderson, B.D. Ve Spector, A. (2000). Introduction to Pilates-based Rehabilitation. Orthopaedic Physical Therapy Clinics of North America, 9(3), 395410.

Archer, S. (2004). Pilates fusion: Well-being for body, mind, and spirit. San Francisco: ChronicleBooks.

Aybek, A.,ve Yıldıran, İ. (2016). Baron Pierre de Coubertin'in olimpizm felsefesinde kadın. İçinde, C. Koca (der.). Sporun Toplumsal Cinsiyet Halleri (s. 58-77). Ankara: Spor Yayınevi.

Bandy, S. J. (2000). Women \& sport: From antiquitytothe 19th century. Olympic Review, 31, 18-22.

Bonde, H. (2003). Masculine sport and masculinity in Denmark at the turn of the century. İçinde, ( Ervo, S. ve Johannson, T. der.) Among Men: Moulding Masculinities. (s. 81-114). Hants: Ashgate

Bora, T. (2013). Futbolda erkeklik, militarizm, milliyetçilik: Tek kale. İçinde, (N. Y.Sünbüloğlu, der.) Erkek Millet Asker Millet: Türkiye'de Militarizm, Milliyetçilik, Erkeklikler. (s. 487-511). İstanbul: İletişim. 
Bora, T. (2010). Erkeklik ve futbol. İçinde, (U. Güner, ve S. Varol, der.) Orada Kimse Var Mi? (s. 37-41). Ankara: Kaos GL.

Bozok, N. (2019). Herkesle ve kimsesiz, türler arasında ve kimsesiz Siborg: Donna Haraway'in düşüncesinde feminist bir beden politikasının imkanlar1. Vira Verita, 9, 128-148.

Bryson, L. (1987). Sport and the maintenance of masculine hegemony. Women's Studies International Forum, 10(4), 349-360.

Bulgu, N. (2012). Futbolda şiddetin erkeklik anlamları. Hacettepe Spor Bilimleri Dergisi, 23(4), 207-219.

Caldwell, K., Harrison, M., Adams, M. ve Triplett, N. T. (2009). Effect of pilates and taiji quan training on self-efficacy, sleepquality, mood, and physical performance of college students. Journal of Bodywork and Movement Therapies 13(2), 155-163.

Chalabaev, A., Sarrazin, P., Fontayne, P., Boiché, J. ve Clément-Guillotin, C. (2013). The influence of sex stereotypes and gender roles on participation and performance in sport and exercise: Review and future directions. Psychology of Sport and Exercise, 14, 136-144.

Coffey, J. (2013). 'Body pressure': Negotiating gender through body work practices. Youth Studies Australia, 32(2), 39.

Connell, R. W. (2005). Masculinities. Berkeley: University of California Press.

Connell, R. W. (2000). The men and the boys. St. Leonards: Allen \& Unwin.

Connell, R. W. (1998). Toplumsal cinsiyet ve iktidar: Toplum, kişi ve cinsel politika. (C. Soydemir, Çev.). İstanbul: Ayrıntı.

Connell, R. W. ve Messerschmidt, J. W. (2005). Hegemonic masculinity: rethinking the concept. Gender and Society, 19(6), 829-859.

Cruz-Ferreira, A.,Fernandes, J., Gomes, D., Bernardo, L. M., Kirkcaldy, B. D., Barbosa, T. M. ve Silva, A. (2011). Effects of pilates-based exercise on life satisfaction, physical self-concept and health status in adult women. Women \& Health, 51(3), 240-255.

Csizma, K. A.,Wittig, A. F., ve Schurr, K. T. (1988). Sport stereotypes and gender. Journal Of Sport And Exercise Psychology, 10(1), 62-74.

Emir, E. Karaçam, M. Ş., ve Koca, C. (2016). Kadın boksörler: Boks ringinde ve ringin dışında sürekli eldiven giymek. Hacettepe Spor Bilimleri Dergisi, 26(4), 136-153.

Erdemli, A. (2012). Kadın ve spor. Kadın Araştırmaları Dergisi, 5, 95-126. 
Gillett, J. ve White, P. G. (1992). Male bodybuilding and the reassertion of hegemonic masculinity: A critical feminist perspective. Play $\mathcal{E}$ Culture, 5(4), 358-369.

Goldberg, H. (2018).Erkek olmanın tehlikeleri. (S. Budak, çev.). İstanbul: Totem Yayıncilik.

Güner, A. (Yönetmen) ve Güneyer, T. (Yapımcı) (2008-2010). Adanalı [Televizyon Dizisi]. Adana: ATV.

Hacısoftaoğlu, İ. (2012). Burası er meydanı: Güreşte erkekliğin inşası. Doktora tezi. Hacettepe Üniversitesi, Ankara.

Hacısoftaoğlu, İ. ve Bulgu, N. (2015). Yedi dağın ötesindeki çocuklar: Güreşte erkeklik ve şiddet. İçinde, (B. Yarar, der.) Şiddetin cinsiyetli yüzleri. (s. 113-140). İstanbul: İstanbul Bilgi Üniversitesi Yayınları.

Hacısoftaoğlu, İ. ve Elmas, S. (2015). Kasların efendisi: Men's health dergisinde fitness söylemi. fe dergi 7(2),21-34.

Hardin, M. ve Greer, J. D. (2009). The influence of gender-role socialization, media use and sports participation on perceptions of gender-appropriate sports. Journal of Sport Behavior, 32(2), 207-226.

Hearn, J. (2008). The personal is work is political is theoretical: continuities and discontinuities in women's studies, (Pro)feminism, "men" and my selves. NORA- Nordic Journal of Feminist and Gender Research, 16(4),241-256.

Hünler, O. S. (2018). Erkekliğin imkansız kaslarla imtihanı. İçinde, (A. Bora, Ve K. Dede, der.) Ütopyalar: Politikayla Arzunun Kesiştiği Yer. (s. 237258). İstanbul: İletişim.

Jackson, D. (2016). Exploring aging masculinities: The body, sexuality and social lives. Londra: Palgrave Macmillan.

Jago, R.,Jonker, M. L., Missaghian, M. ve Baranowski, T. (2006). Effect of 4 weeks of pilates on the body composition of young girls. Preventive Medicine, 42(3), 177-180.

Johnson, E. G., Larsen, A., Ozawa, H., Wilson, C. A. ve Kennedy, K. L. (2007). The effects of pilates-based exercise on dynamic balance in healthy adults. Journal Of Bodywork And Movement Therapies, 11(3), 238-242.

Kavasoğlu, İ. ve Yıkılmaz, A. (2018). Şampiyonluk ve yenilgi arasında bir kimlik: Wushu'da üretilen erkeklik formları. СBÜ Beden Eğitimi ve Spor Bilimleri Dergisi, 13(2), 318-341. 
Kavasoğlu, İ., ve Yıldıran, İ. (2016). Erken Cumhuriyet döneminde kadın sporcular üzerinden modern kadın okumaları. İçinde, (C. Koca, der.). Sporun Toplumsal Cinsiyet Halleri (s. 94-113). Ankara: Spor Yayınevi.

Kavasoğlu, İ., Rençbereli, M., ve Yenel, İ. F. (2017). Dans eden "erkek adamlar": Erkek dansçıların deneyimlerine toplumsal cinsiyet analizi. Journal of Human Sciences, 14(2), 1768-1780.

Kimmel, M. S. (2013). Homofobi olarak erkeklik: Toplumsal cinsiyet kimliğinin inşasında korku, utanç ve sessizlik. (M. Bozok, çev.) fe dergi, 5(2), 92-107. 14.04.2019 tarihinde http://cins.ankara.edu.tr/10 12.pdf adresinden erişilmiştir.

Koca, C. (2016). Cinsiyetlendirilmiş bir alan olarak spor. (C. Koca Ed.). Sporun Toplumsal Cinsiyet Halleri içinde (s. 18- 37). Ankara: Spor Yayınevi.

(2006). Beden eğitimi ve spor alanında toplumsal cinsiyet ilişkileri. Hacettepe Spor Bilimleri Dergisi, 17 (2), 81-99.

Koca, C. ve Bulgu, N. (2005). Spor Ve toplumsal cinsiyet: genel bir bakış. Toplum ve Bilim, 103, 163- 181.

Koca, C. ve Demirhan, G. (2005). Beden eğitimi ve spor alanında toplumsal cinsiyetin yeniden üretimi. Hacettepe Spor Bilimleri Dergisi, 16 (4), 200228.

Koivula, N. (2001). Perceived characteristics of sports categorized as genderneutral, Feminine And Masculine. Journal of Sport Behavior. 24(4), 377393.

Koivula, N. (1999). Gender stereotyping in televised media sport coverage. Sex Roles, 41(7-8), 589-604.

Koivula, N. (1995). Ratings of gender appropriateness of sports participation: effects of gender-based schematic processing. Sex Roles, 33(7-8), 543557.

Light, R. ve Kirk, D. (2000). High school rugby, The body and the reproduction of hegemonic masculinity. Sport, Education And Society, 5(2), 163176.

Markula, P. (2008). Affect[İng] bodies: Performative pedagogy of pilates. International Review Of Qualitative Research, 1(3), 381-408.

Markula, P. (2006). Deleuze and the body without organs: Disreading the fit feminine 1dentity. Journal of Sport and Social Issues, 30(1), 29-44.

Markula, P. (2004). "Tuning into One's Self:" Foucault's technologies of the self and mindful fitness. Sociology Of Sport Journal, 21(3), 302-321. 
Matteo, S. (1988). The effect of gender-schematic processing on decisions about sex-1 nappropriate sport behavior. Sex Roles, 18(1/2), 41-58.

Matteo, S. (1986). The effect of sex and gender-schematic processing on sport participation. Sex Roles, 15(7-8), 417-432.

McKay, J., Messner, M. ve Sabo, D. (2000). Studying sport, men, and masculinities from feminist standpoints. İçinde, ( J. McKay; M. A. Messner ve D. Sabo der.), Research on Men and Masculinities: Masculinities, Gender Relations, and Sport (s. 2-12). Thousand Oaks, CA: Sage Publications.

Messner, M. A. (2007). Introduction: Gender and sports. İçinde, (M. A. Messner, der.) Out of play: Critical essays on gender and sport. (s. 1-7). Albany: State University of New York Press.

Messner, M. A. (2005). Still a man's world? Studying masculinities and sport. İçinde Kimmel, M., Hearn, J. ve (R. W. Connell, der.) Handbook of Studies on Men and Masculinities. (ss. 313-325).Thousand Oaks: Sage.

Messner, M. A. (2000). Barbie girls versus sea monsters: Children constructing gender. Gender $\mathcal{E}$ Society, 14, 765-784.

Messner, M. A. (1992). Power at play: Sports and the problem of masculinity. Boston: Beacon.

Messner, M. A. (1988). Sports and male domination: The female athlete as contested ideological terrain. Sociology Of Sport Journal, 5(3), 197-211.

Messner, M. A., Duncan, M. C., ve Jensen, K. (1993). Separating the men from the girls: The gendered language of televised sports. Gender $\mathcal{E}$ Society, 7(1), 121-137.

Mokhtari, M., Nezakatalhossaini, M. ve Esfarjani, F. (2013). The effect of 12week pilates exercises on depression and balance associated with falling in the elderly. Procedia - Social and Behavioral Sciences, 70, 17141723.

Morrow, R. G. ve Gill, D. L. (2003). Perceptions of homophobia and heterosexism in physical education. Research Quarterly For Exercise And Sport, 74(2), 205-214.

Mortaş, N. (2009). Bedenle mücadeleye dönüşen bir yaşlanma pratiği. DoğuBatı, 48, 173-184.

Nguyen, A. (2008). Patriarchy, power, and female masculinity. Journal of Homosexuality, 55(4), 665-683. 
O'Brien, K. S.,Shovelton, H. ve Latner, J. D. (2013). Homophobia in physical education and sport: The role of physical/sporting 1dentity and attributes, authoritarian aggression, and social dominance orientation. International Journal of Psychology, 48(5), 891-899.

Özbay, C. (2013). Türkiye' de hegemonik erkekliği aramak. Doğu Batı, 63, 185204.

Özkul, Ç. (2017). Multipl Skleroz hastalarında aerobik eğitimle kombine pilates eğitiminin biyokimyasal faktörler, fiziksel performans, yorgunluk ve yaşam kalitesi üzerine etkilerinin incelenmesi. Doktora Tezi. Gazi Üniversitesi, Ankara.

Öztürk, P. (2016). Sporda toplumsal cinsiyet çalışmalarının tarihsel seyri. İçinde, (C. Koca, der.), Sporun Toplumsal Cinsiyet Halleri (s. 38- 55). Ankara: Spor Yayınevi.

Öztürk, P. ve Karaçam, M. (2017). Spor bilimlerinde LGBTQİ çalışmaları. KAOS GL Kültür ve Yaşam Dergisi, 153, 53-64.

Parker, A. (1997). Sporting masculinities: Gender relations and the body. İçinde, (Mac and M. Ghaill, der.), Understanding Masculinities: Social Relations and Cultural Arenas (s. 126-138). Buckingam, PA: Open University Press.

Patton, M.Q. (2014). Nitel araştırma ve değerlendirme yöntemleri. İçinde, (M. Bütün, ve S. B. Demir, der.), Ankara: Pegem.

Riemer, B. A. ve Visio, M. E. (2003). Gender typing of sports: An investigation of metheny's classification. Research Quarterly for Exercise ve Sport, 74, 193-204.

Sancar, S. (2009). Erkeklik: İmkânsiz iktidar: Ailede, piyasada ve sokakta erkekler. İstanbul: Metis Yayınları.

Schmalz, D. L., ve Kerstetter, D. L. (2006). Girlie girls and manly men: Chidren's Stigma consciousness of gender in sports and physical activities. Journal of Leisure Research, 38(4), 536-557.

Selek, P. (2013). Sürüne sürüne erkek olmak. İstanbul: İletişim Yayınları.

Selek, P. (2008). Akıllı ol!. içinde, (N. Mutluer, der.) Cinsiyet halleri: Türkiye'de toplumsal cinsiyetin kesişim sinırları (s. 220-231). İstanbul: Varlık.

Sezgin, D. (2011). Yaşam tarzı önerileri bağlamında sağlık haberlerinin analizi. Ankara Üniversitesi Sosyal Bilimler Dergisi, 2(2), 52-78.

Siler, A. (2000). The pilates body: The ultimate at-home guide to strengthening, lengthening and toning your body without machines. New York: Random House. 
Solomon-Godeau, A. (1997). Male trouble: A crisis in representation (p. 214). London: Thames and Hudson.

Sungur, A. (2011). Masculinity and honour perception: A case study in Tepebağ district Adana-Turkey. Yayımlanmamış Yüksek Lisans Tezi. Ankara: ODTÜ Sosyal Bilimler Enstitüsü.

Talimciler, A. (2006). İdeolojik bir meşrulaştırma aracı olarak spor ve spor bilimleri. Spor Yönetimi ve Bilgi Teknolojileri, 1(2), 35-40.

Taşdelen, P. ve Koca, C. (2015). Viktorya dönemi İngiltere'sinde kadın bedeni politikaları ve kadınların spora katılımı. Hacettepe Üniversitesi Edebiyat Fakültesi Dergisi, 32, 205-214.

Taşkın, K. B. (2016-2019). Sıfır Bir - Bir Zamanlar Adana'da [Internet Dizisi]. İstanbul: BluTV. Erişim, 10.4.2019, https://www.blutv.com.tr/adana-sifir-bir-izle

Tingaz, E.O. (2018). Sağlıklı yetişkin kadınlarda uygulanan 8 haftalık mat pilates egzersizinin düşünme stilleri, psikososyal uyum ile mizaç ve karakter üzerine etkisi. Doktora tezi. Gazi Üniversitesi, Ankara.

Tokdoğan, N. (2015). Dövüş sporları ve erkeklik: Tekvandocu erkekler ve erkeklik üzerine bir etnografi denemesi. İçinde, (İ. Hacısoftaoğlu, F. Akcan, ve N. Bulgu der.), Oyunun ötesinde (s.231-265) içinde. Ankara: Notabene Yayınları.

Türker, Y. (2004). Erk ile erkek. Toplum ve Bilim, 101, 8-10.

Ungaro, A. (2002). Pilates: Body in motion. Londra: Dorling Kindersley Publishing.

Vigue, S. (2015). Pilates for men: Build a strong and athletic body anywhere, anytime. 10.05.2019 tarihinde http://www.seanviguefitness.com/books/pilates-for-men/ adresinden erişilmiştir.

Wellard, I. (2009). Sport, masculinities and the body. Londra: Routledge.

\section{Kaynakça Bilgisi / Citation Information}

Bozok, M., Munar, M. ve Kavasoğlu, İ. (2019). Cinsiyetlendirilmiş bir egzersizin sınırlarında: Adana'daki erkeklerin pilates deneyimleri. OPUS-Uluslararası Toplum Araştırmaları Dergisi , 13(19), 1721-1756. DOI: $10.26466 /$ opus.587527 